\title{
ANALISIS KUALITATIF DAN KUANTITATIF KANDUNGAN FORMALIN PADA PRODUK TERASI (Shrimp Paste) YANG DIPERDAGANGKAN DI PASAR SENTRAL KOTA DAN PASAR SENTRAL WUA-WUA
}

\author{
[Qualitative And Quantitative Analysis of Shrimp Paste Formalin Content Traded in City Central Market and Wua-Wua \\ Central Market]
}

\author{
Wayan Hardinata $\left.{ }^{1}\right)^{*}$, La Karimuna²), Nur Asyik ${ }^{1}$ ) \\ 1Jurusan Ilmu dan Teknologi Pangan, Fakultas Pertanian, Universitas Halu Oleo, Kendari \\ 2Jurusan Agroteknologi Fakultas Pertanian, Universitas Halu Oleo, Kendari \\ Email: wayan.hardinata@gmail.com Telp: 082292522925
}

Diterima tanggal 14 Juni 2019,

Disetujui tanggal 06 Juli 2019

\begin{abstract}
This study aimed to determine the formalin content of shrimp paste traded in the City Central Market and Wua-Wua Central Market. The analytical method used was the Phenylhydrazine method and quantitative test (Titration Method). The qualitative test was done to determine the presence or absence of formalin in the shrimp paste, while the quantitative test was done to determine the amount of formalin contained in the shrimp paste traded in the City Central Market and the WuaWua Central Market. This was a descriptive qualitative-quantitative study. The results of this study show that from 6 samples taken at the City Central Market and the Wua-Wua Central Market, five samples were positive for formalin. The average amount of formalin contents at the City Central Market were $77 \mathrm{mg} / \mathrm{kg}$ (A2) and $54.6 \mathrm{mg} / \mathrm{kg}$ (A3). Meanwhile, the average amount of formalin contents at the Wua-Wua Central Market were $60 \mathrm{mg} / \mathrm{kg}$ (B1), $66.7 \mathrm{mg} / \mathrm{kg}$ (B2), and $107.2 \mathrm{mg} / \mathrm{kg}$ (B3).
\end{abstract}

Keywords: Shrimp paste, Formalin, Traditional market

\section{ABSTRAK}

Penelitian ini bertujuan untuk mengetahui kandungan formalin pada terasi yang diperdagangkan di Pasar Sentral Kota dan Pasar Sentral Wua-Wua. Metode analisis yang digunakan yaitu metode Fenilhidrazin dan uji kuantitatif (Metode Titrasi). Uji kualitatif bertujuan untuk mengetahui ada tidaknya formalin pada terasi, sedangkan uji kuantitatif bertujuan untuk mengetahui berapa kadar formalin yang terkandung pada terasi yang diperdagangkan di Pasar Sentral Kota dan Pasar Sentral Wua-Wua. Jenis penelitian ini yaitu deskriptif kualitatif dan kuantitatif. Hasil penelitian ini memberikan informasi bahwa sampel yang diambil dari 6 sampel Pasar Sentral Kota dan Pasar Sentral Wua-Wua 5 sampel positif mengandung formalin. Rata-rata persentase kadar formalin di lokasi Pasar Sentral Kota (A2) sebesar $77 \mathrm{mg} / \mathrm{kg}$ dan 54,6 mg/kg (A3). Pasar Sentral Wua-Wua (B1) 60 mg/kg, (B2) 66,7 mg/kg dan (B3) 107,2 mg/kg. Hasil penelitian menghasilkan simpulan terdeteksinya penggunaan formalin pada 5 sampel produk terasi yang beredar di lokasi Pasar Sentral Kota dan Pasar Sentral Wua-Wua kota Kendari.

Kata kunci: Terasi, Formalin, Pasar tradisional. 


\section{PENDAHULUAN}

Terasi adalah salah satu produk hasil fermentasi ikan atau udang yang hanya mengalami perlakuan penggaraman (tanpa diikuti dengan penambahan asam) kemudian di biarkan beberapa saat agar terjadi proses fermentasi (Suwandi et al., 2017). Terasi yang bermutu menurut Suprapti (2002) yaitu berwarna gelap, tidak terlalu keras dan lembek. Dengan kandungan protein $15-20 \%$, terasi sangat baik sebagai penyedap makanan. Nilai gizi yang terdapat pada terasi yaitu protein, lemak, karbohidrat, mineral, kalsium, fosfor,besi dan air.

Terasi merupakan produk olahan hasil perikanan yang mudah rusak, sehingga banyak produsen yang menambahkan bahan tambahan pangan dalam terasi olahannya. Secara umum yang dimaksud dengan bahan tambahan, Penggunaan bahan tambahan pangan (BTP) bertujuan meningkatkan atau mempertahankan nilai gizi dan kualitas daya simpan, membuat bahan pangan lebih mudah dihidangkan, serta mempermudah preparasi bahan pangan. Untuk menghindari dan mengurangi kemungkinan pencemaran suatu produk oleh mikroorganisme, dilakukan proses pengawetan produk. Syarat zat pengawet adalah mampu membunuh kontaminan mikroorganisme, tidak toksik atau menyebabkan iritasi pada pengguna, stabil dan aktif, tidak bereaksi dengan bahan (Harianti, 2011).

Umumnya, bahan tambahan yang ditambahkan dalam terasi yaitu zat pengawet. Zat pengawet sendiri merupakan bahan tambahan yang bertujuan untuk memperpanjang umur simpan suatu produk. Namun, banyak produsen yang menyalahi aturan dalam menggunakan bahan pengawet. Pengawet yang biasa ditambahkan yaitu formalin. Formalin biasanya digunakan sebagai pembersih lantai, pembersih kapal, bahan baku industri lem, pembasmi lalat dan serangga lainnya. Larutan formalin sering dipakai membalsem atau mematikan bakteri serta mengawetkan mayat, tetapi formalin telah disalahgunakan untuk mengawetkan makanan (Hastuti, 2010). Menurut Fadli (2016), terasi yang diperdagangkan dipasar tradisional kota Kendari (pasar Baruga, pasar Panjang, pasar Andonohu dan pasar Basah) mempunyai kadar formalin yang berbeda-beda, dimana dari 8 sampel terasi yang diteliti mengandung formalin dengan kadar terdiri $100 \mathrm{mg} / \mathrm{kg}$ dan kadar tertinggi $160 \mathrm{mg} / \mathrm{kg}$. Pasar tradisional merupakan tempat umum yang banyak menjual berbagai macam produk makanan termasuk terasi. Penyalahgunaan bahan tambahan pangan di Indonesia begitu marak, tidak terkecuali di Kota Kendari Provinsi Sulawesi Tenggara. Terutama penambahan pengawet yang tidak diizinkan seperti formalin.

Berdasarkan uraian diatas, maka dilaporkan hasil penelitian tentang analisis kualitatif dan kuantitatif kandungan formalin pada produk terasi (Shrim Paste) yang diperdagangkan di pasar Sentral Kota dan pasar Sentral Wua-wua di kota Kendari. 


\section{BAHAN DAN METODE}

\section{Bahan}

Bahan yang digunakan yaitu terasi, $\mathrm{KMnO}_{4}$ (teknis), $50 \mathrm{~mL} \mathrm{NaOH} \mathrm{0,1} \mathrm{N} \mathrm{(teknis),} 25 \mathrm{~mL} \mathrm{H}_{2} \mathrm{O}_{2}$ (teknis), 2 tetes metil jingga (indikator pp) (teknis) dan $\mathrm{HCl} 0,1 \mathrm{~N}$ (teknis).

\section{Analisis Kualitatif}

Analisis formalin dapat dilakukan untuk menyatakan ada tidaknya formalin dalam suatu bahan yang diuji dengan cara menambahkan pereaksi kimia (reagen) tertentu pada bahan yang diduga mengandung formalin sehingga dihasilkan suatu perubahan warna yang khas (Widyaningsih dan Murtini, 2006). Pereaksi kimia yang digunakan dalam pengidentifikasi formalin yaitu kalium permanganat (KMnO4). Adanya formalin ditunjukan oleh hilangnya warna merah muda dari $\mathrm{KMnO} 4$.

\section{Analisis Kuantitatif}

Analisis kuantitatif pada penelitian ini dilakukan dengan menggunakan metode titrasi. Memulai dengan mengambil sampel terasi $5 \mathrm{~g}$ dan disimpan dalam gelas ukur, kemudian menambahkan $30 \mathrm{ml}$ aquades setelah itu disaring dan diambil filtratnya sebanyak $10 \mathrm{ml}$, setelah itu di tambahakan $25 \mathrm{ml} \mathrm{H}_{2} \mathrm{O}_{2}$, kemudian ditambahkan 50 $\mathrm{ml} \mathrm{NaOH} \mathrm{0,1} \mathrm{N} \mathrm{kemudian} \mathrm{ditambahkan} 2$ tetes metil jingga (indikator pp) dan dititrasi dengan $\mathrm{HCl} 0,1 \mathrm{~N}$ untuk mengukur volume dan kurva standar formalin pada sampel terasi.

\section{HASIL DAN PEMBAHASAN}

\section{Analsisis Kualitatif}

Hasil uji kualitatif formalin pada produk terasi yang diperdagangkan dipasar Sentral Kota dan pasar Sentral Wua-wua dapat dilihat pada Tabel 1.

Tabel 1. Hasil identifikasi formalin pada produk terasi.

\begin{tabular}{ccc}
\hline No & Kode Sampel & Formalin (Formaldehid) \\
\hline 1 & A1 & - \\
2 & A2 & + \\
3 & A3 & + \\
4 & B1 & + \\
5 & B2 & + \\
6 & B3 & + \\
\hline
\end{tabular}

Keterangan: + (Positif), - (Negatif), A1 - A3 = Pasar Sentral Kota dan B1 - B3 = Pasar Sentral Wua-Wua 
Berdasarkan hasil pengamatan pada Tabel 1 dapat diketahui bahwa dari 6 sampel terasi yang diuji terdapat 5 sampel positif mengandung formalin. Sampel yang mengandung formalin ditandai oleh hilangnya warna merah muda dari $\mathrm{KMnO}_{4}$. Marwanti (2013) melaporkan bahwa kalium permanganat merupakan peraksi spesifik dari formalin. Oleh karena itu kalium permanganat dapat digunakan untuk pengujian formalin pada sampel - sampel yang diduga mengandung formalin.

Terasi yang diuji secara kualitatif ke 5 sampel yang mengandung formalin yakni berasal dari Pasar Sentral Kota (A2), Pasar Sentral Kota (A3), Pasar Sentral Wua-wua (B1), Pasar Sentral Wua-wua (B2) dan Pasar Sentral Wua-wua (B3). Dari hasil diatas dapat disimpulkan bahwa terasi yang diperdagangkan di Pasar Sentral Kota dan Pasar Sentral Wua-wua tidak aman untuk dikonsumsi karena telah mengandung formalin, sehingga dari penelitian ini perlu ditingkatkan kesadaran masyarakat akan keamanan pangan.

\section{Analisis Kuantitatif}

Hasil analisis kuantitatif formalin pada produk terasi yang diperoleh dari beberapa pasar Sentral Kota dan pasar Sentral Wua-wua disajikan pada Tabel 2.

Tabel 2. Hasil analisis kuantitatif formalin

\begin{tabular}{cc}
\hline Kode Sampel & Kosentrasi $(\mathrm{mg} / \mathrm{g})$ \\
\hline A2 & 77 \\
A3 & 54,6 \\
B1 & 60 \\
B2 & 66,7 \\
B3 & 107,2 \\
\hline
\end{tabular}

Keterangan : + (Positif), - (Negatif), A1 - A3 = Pasar Sentral Kota dan B1 - B3 = Pasar Sentral Wua-Wua

Berdasarkan hasil uji kuantitatif dengan menggunakan metode analisis volumetri, hasilnya dapat dilihat pada Tabel 2 yaitu tiap-tiap sampel memiliki kadar formalin yang berbeda-beda, dimana kadar formalin untuk Pasar sentral kota dengan kode sampel A2 memiki kadar formalin 7,7 mg/kg dan A3 dengan kadar 54,6 mg/kg, kadar formalin pada sampel dari Pasar sentral wua-wua (Pasar baru) dengan kode sampel B1 memiliki kadar formalin $60 \mathrm{mg} / \mathrm{kg}$, B2 dengan kadar 66,7 mg/kg dan B3 dengan kadar 107,2 mg/kg. Hasil penelitian menunjukan bahwa terasi yang dijual di pasar sentral kota dan pasar sentral wua-wua yang diidentifikasi secara akurat dan meyakinkan melalui pengujian laboratorium diketahui kadar formalin terendah terdapat di pasar sental kota A3 dengan kadar $54,6 \mathrm{mg} / \mathrm{kg}$ dan kadar formalin yang tinggi terdapat pada pasar sentral wua-wua dengan kode sampel B3 yaitu 107,2 mg/kg. 
Wulan (2015) melaporkan bahwa masing-masing sampel bakso memiliki kadar formalin yang bervariasi. Kadar formalin tertinggi pada sampel C sebesar $1,510 \mu \mathrm{g} / \mathrm{g}$, berikutnya sampel D13 sebesar 1,086 $\mu \mathrm{g} / \mathrm{g}$ dan sampel B1 sebesar 0,442 $\mu \mathrm{g} / \mathrm{g}$ dan kadar terendah terdapat pada sampel B2 sebesar 0,321 $\mu \mathrm{g} / \mathrm{g}$. Mukminah (2018) melaporkan bahwa 33\% siomay tahu yang diperdagangkan tidak mengandung formalin sehingga aman untuk dikonsumsi dan 67\% sampel yang mengandung formalin sehingga tidak aman untuk dikonsumsi, dari 67\% sampel yang mengandung formalin didapatkan kadar tertinggi yaitu 57,2 mg/g dan yang terendah yaitu 15,6 mg/g.

Berdasarkan pernyataan tersebut, dapat memperkuat dugaan bahwa tingginya kadar formalin yang terkandung pada terasi yang merupakan asal terasi yang diambil untuk dipasarkan itu berasal dari beberapa tempat pengolahan terasi tersebut. Tingginya kadar formalin juga diduga berdasarkan wawancara koesioner bahwa terasi yang lama habis terjual disebabkan karena para pedagang terlalu banyak stok yang disediakan, sehingga kadar formalin pada terasi yang paling tinggi yaitu 107,2 mg/kg. Fadli (2016) melaporkan bahwa 100\% terasi yang diperdagangkan dipasar tradisional kota Kendari mengandung formalin sehingga tidak aman untuk dikonsumsi, dari ke 8 sampel memiki kadar tertinggi $160 \mathrm{mg} / \mathrm{kg}$ dan kadar terendah $100 \mathrm{mg} / \mathrm{kg}$. Jika dibandingkan dengan penelitian Fadli (2016), dari pasar tradisional kota Kendarii (pasar baruga, pasar panjang, pasar andonohu dan pasar basah) lebih tinggi yaitu $160 \mathrm{mg} / \mathrm{kg}$ dibandingkan darii pasar sentral kota dan pasar sentral wua-wua memiliki kadar paling tinggi 107,2 mg/kg.

Sedangkan yang terendah diduga karena terasi yang diproduksi dari tempat tersebut menambahkan formalin yang cukup rendah, dalam kata lain masih dalam jumlah sedikit. Meskipun jumlah terendah adalah 54,6 $\mathrm{mg} / \mathrm{g}$, namun tetap tidak bisa untuk dikonsumsi dikarenakan jumlah tersebut masih tinggi dibandingkan dari ambang batas toleransi tubuh.

\section{KESIMPULAN}

Berdasarkan hasil uji kualitatif terdapat 5 sampel terasi yang teridentifikasi mengandung formalin dan terdapat 1 sampel yang negatif mengandung formalin. Kadar formalin yang terendah yaitu berasal dari pasar Sentral Kota dengan kadar 54,6 mg/kg dan kandungan tertinggi yaitu berasal dari pasar Sentral Wua-wua dengan kadar $107 \mathrm{mg} / \mathrm{kg}$. Hasil penelitian ini menunjukkan terdeteksinya penggunaan formalin pada 5 sampel produk terasi yang beredar di lokasi Pasar Sentral Kota dan Pasar Sentral Wua-Wua kota Kendari. 


\section{DAFTAR PUSTAKA}

Fadli, R.A., Ibrahim, M.N dan Sardimantara, M.S. 2016. Analisis Kandungan Zat Pengawet Formalin pada Terasi yang Diperdagangkan di Pasar Tradisional Kota Kendari. Jurnal Sains dan Teknologi Pangan. 1(1):7378

Harianti. 2011. Alternatif Bahan Tambahan Pangan Sebagai Pengawet Produk Perikanan. Jurnal Balik Diwa. 2(2):7-14

Hastuti, S. 2010. Analisis Kualitatif dan Kuantitatif Formaldehid pada Ikan Asin di Madura. Jurnal Agrointek. 4(2):132-137.

Mukminah, S., Karimuna, L dan Asyik, N. 2018. Analisis Kandungan Formalin pada Somai Tahu yang Beredar Dibeberapa Sekolah Dasar Kecamatan Baruga Kota Kendari. Jurnal Sains dan Teknologi Pangan. 4(2):143-149

Suprapti, M.L. 2002. Membuat Terasi (Teknologi Tepat Guna). Kanisius. Yogyakarta.

Suwandi., Rohanah, A dan Rindang, A. 2017. Uji Komposisi Bahan Baku Terasi dengan Menggunakan Alat Pencetak Terasi. Jurnal Rekayasa Panganda Pertanian. 5(1):196-201

Widyaningsih, T.D dan Murtini, E.S. 2006. Alternatif Pengganti Formalin pada Produk Pangan. Trubus Agrisarana. Jakarta.

Wulan, S. 2015. Identifikasi Formalin Pada Bakso dari Pedagang Bakso di Kecamatan Panakukkang Kota Makassar. Skripsi. Program Studi Kedokteran Hewan, Fakultas Kedokteran, Universitas Hasanuddin. Makassar. 